\title{
The New Ustad in Religious Authority: Challenge and Dynamic of Fatwa in the New Media Era
}

\author{
$1^{\text {st }}$ M. Akhfas Syifa Afandi ${ }^{1}, 2^{\text {nd }}$ Arif Rofiuddin ${ }^{2}, 3^{\text {rd }}$ Arif Zamhari ${ }^{3}, 4^{\text {th }}$ Yusuf Rahman $^{4}$, \\ $5^{\text {th }}$ Ade Rina Farida ${ }^{5}, 6^{\text {th }}$ Andi M Faisal Bakti ${ }^{6}$ \\ \{mas.achfas@gmail.com ${ }^{1}$, arif18@ gmail.com², arif.zamhari@uinjkt.ac.id ${ }^{3}$, yusuf.rahman@uinjkt.ac.id ${ }^{4}$, \\ ade.rina.farida@uinjkt.ac.id ${ }^{5}$, andi.faisal@uinjkt.ac.id $\left.{ }^{6}\right\}$ \\ Sy arif Hiday atullah State Islamic University of Jakarta, Indonesia ${ }^{1,3,4,5,6}$ \\ University of Indonesia, Jakarta, Indonesia ${ }^{2}$
}

\begin{abstract}
This research aims to analyze the effect of digital media on Indonesia's evolving religious authority. A qualitative approach with a description-analysis framework was used by researchers based on a literature review as a data source. Therefore, this study explains how information development in the new media era can alter social, political, economic, and religious authority, including how fatwa is often transmitted by those who do not have integrity and profound scientific capacity. The results of this study assert that, in addition to providing easy access to information, the changes in the era of new media also raise concern that someone with the profound scientific ability no longer transmits fatwa. They are known as the 'new Ustaz,' a term that refers to a character who suddenly becomes a cleric without going through a series of old intellectual contemplation and education. It may potentially affect religious confusion, which creates uproar and friction in society.
\end{abstract}

Keywords: Fatwa, Religious Authorities, New Media

\section{Introduction}

Technological developments have caused many changes in every aspect of life. Indeed, every space and time can not be separated from intervention technology and assistance, particularly in the new media era.[1] The Internet has brought about many social, political, economic, and cultural aspects and ritual practices and religious norms such as the sacredness of fatwa and critical thinking history in religion.

Essential changes included a shift in religious authority and adherents' engagement with religious leaders (ulama) who became role models in everyday life. Previously, the religious authority was held only by the ulama (Kiai or Ustad). Still, now the religious authority is experiencing a change to new media that looks impersonal and is centered on information networks (Internet).[2] Everyone can easily access information according to their unique tastes and needs. A person who needs an answer to a problem does not have to ask the ulama specifically since religious fatwa no longer belongs to conventional ulama alone. Still, everyone can easily find solutions and make decisions based on media information.

This is a problem because fatwa is very strategic in Islam. A capacity of mufti (giver of fatwa) - as al-Syatibi said - acts as Prophet Saw' heir. To convey the sharia law, to teach religious knowledge, and to remind those who neglect it.[3] This appraisal is based on the understanding that it is not easy to profess a mufti; at least one must have in-depth knowledge 
and mastery of religious scholarship. And for this reason, the scholars have limitations in generating fatwa, which is their values.[4]

In Indonesia, the discussion on fatwa continues to develop, whether collectively, such as the Indonesian Council of Ulama (MUI), Nahdlatul Ulama (NU), Muhammadiyah, and fatwa produced by individual ulama. Furthermore, Indonesia's research and discussion on fatwa dynamics are also experiencing development and increasing criticism. For starters, on February 13, 2009, many legal opinions (fatwa) that later drew a lot of reactions in the society, the MUI fatwa, about the abstention prohibition, [5] fatwa concerning conventional banks on December 16, 2003,[6] and in 2005, fatwa number seven about pluralism, tolerance, and secularism.[7]

Another topic of equal importance is the ease of internet access to a religious fatwa (question and answer forums). So it has added new problems and complexities of religious affairs in matters of the fatwa that need to be taken into consideration. When this trend is left unchecked, what will arise are those who tend to think selectively. Hence, it contributes to intolerant thought patterns and behavior and sectarianism that put forth their group's reality and blame different group understandings. Indeed, Islamic values exemplify the importance of pluralism and tolerance. Besides, we need to pay attention to how a person who gives a fatwa has the procedures, methods, and scientific capacity. The purpose of the fatwa in this research is not to discuss conventional fatwa institutions. It has broad goals and objectives, such as fatwa produced by sometimes scientifically incompetent, religious figures on media networks (Internet).

The conclusion, the debate on fatwa amid the development of new media has become attractive for an in-depth discussion. In other words, the discussion of fatwa has become increasingly diverse, not only about the fatwa issued by religious organizations or institutions, [8] but also about fatwa presented individually, especially on the Internet.

\section{Methods}

The authors used a descriptive method with a qualitative approach in this study. This approach analyzes and explains the numerous issues found and how the fatwa authority has undergone significant changes. This research aims to respond to multiple phenomena and social realities in society that are the study's subject. The findings obtained by the authors are then summarized. This study's data were obtained by gathering relevant information from various literature, such as research findings, papers, and books. The data obtained are then analyzed based on empirical induction based on the human experience (based on analysis). Simply put, this study uses sentences to gather data to answer various questions and then ends with a deductive method.

\section{Findings and Discussions}

\subsection{New Media and Religious Authorities}

New media brings with it almost undoubtedly many changes in every line of life. The rapid transfer of knowledge, supposedly accompanied by many social changes, not only in sociocultural, economic but also in religious perspectives. In reality, the word "new media" can be 
used in many areas, such as traditional media, online media, e-media, virtual media, and many more.[9] It can also be described as social media or social networking, which refers to communication built into digital computer networks.[10]

The development of new media can at least be identified with several characteristics . First, new media is a recombinant process created from existing technology with innovations that continue to develop. Second, the use of new media ensures a (networked) relationship that allows two-way communication to be established. Third, as ubiquitous, it ensures that new media is designed as a digital tool to access various information platforms. Fourth, new media becomes an interactive medium for mutual search and sharing that is more practical than old centralized media.[11] This is among the characteristics, instead of what distinguishes it from the consistent, old media.

Previous findings on the Is lamic public have highlighted the importance of digital me dia in shaping and affecting Muslim actions in the public sphere. This is mainly about how democratization and a public division occurred due to the new media's ability to weaken the existing hegemony, such as state and ulama institutions.[1] With its aggressiveness, new media is developing new structures and orders and having a fundamental impact on changing personal minds' patterns beyond one's borders and allowing for traditional religious authority changes.

From a sociological perspective, religious authority is tough to comprehend and not easy to describe. According to Max Weber, authority describes the ability to follow one's rules and decisions without using coercive power. There is no compulsion for Weber, who distinguishes between authority and power (Macht).[12] However, authority and power are not always clearly distinguishable in the present context. Sometimes the two come together in a unified form. The concept of Authority by Weber is understood as a power that has influence and control over others. So the authority has the ability and capability to control others. In this case, the ownership of authority itself is not arbitrary, but certain people may acquire it; that is, it is limited and specific.[13] Nevertheless, religious Authority in Muslim societies is not a new topic. Since its inception, it has attracted scholars interested in the complex interactions between religion, law, politics, and culture.[12] Therefore, it has suffered a technological transformation that makes it easier to access information, including Islam's relatively simple learning. Religious authorities are beginning to shift to a broader position at this stage, not limited to specific groups or organizations, but all society levels.

Also, there has been a transformation of the fatwa authority in the new media era-for instance, the Indonesian Council of Ulama (MUI) — which has been marginalized by the urban ulama that takes the position and role of the state fatwa institution. Their presence in urban communities is quite impressive, as opposed to rural Muslim communities who always follow religious leaders based on their capacity and religious background. Otherwise, the position of "Kiai Kampung" has a traditional authority based on the conventional argument that the leader and followers' beliefs convey virtues, thereby creating a system of relationships (personal attachment).[14]

\subsection{Study of Fatwa Among Indonesian Muslim Scholars}

Definitively, the word al-fatwa-which was later adopted in Indonesian as a fatwa - is a derivation of fata, yaftu, fatwan, which means new, young, and explanation.[15] More specifically, a fatwa is clarified by the faqih or mufti of Islamic law on the topic that has emerged.[16] In this sense, the term 'futya' or 'ifta' is used. A name that refers to giving fatwa can also be interpreted as providing fatwa to a profession.[15] In the meantime, those who give fatwa are known as a mufti, which means Ma'luf, as scholars who give fatwa related to 
sharia matters.[17] Ma'ruf Amin has mentioned the terms regarding this fatwa in several of his books.[18]

Besides, as Wahbah al-Zuhaili has explained, the fatwa is the method of tabyin al-musykil min al-ahkam, or the practice of explaining something that is a problem in Islamic law.[19] A common argument, advanced by Al-Qardlawi, states that a fatwa is an interpretation of Islamic law about a problem, whether it is done directly or not, and whether it is done collectively or individually.[3] The comparable statement, from Khalid Mas'uddan as well.[20] Comprehending the fatwa becomes important from this understanding because: first, the fatwa is a solution to the religious problems faced by society, which is dynamic and flexible in responding to any situation. Many scholars often make changes in the law's decision, such as changes in the Imam Syafi'i madhhab spectrum of qaul qadim and qaul jadid. Second, fatwa activity is a solution to any issue not found in the Quran, hadith, and probably fiqh books. Third, the legal fatwa decision is not binding, and it can still change. But where fatwa decisions are used as the basis for legislation or the judiciary, fatwa status shifts to the critical legal opinion.[8] Fourth, fatwa activities can only be carried out by scholars who have a deep scientific capacity and have learned various disciplines.

Historically, as N.J.G. Kaptein stated, the development of studies and discussions on fatwa in Indonesia has three different typologies: fatwa produced by traditionalist scholars, modernist scholars, and fatwa from certain groups or institutions.[21] The three typologies, a fatwa issued by individual institutions or organizations, such as MUI, Bahtsul Masa'il (NU), Majelis Tarjih wa Tajdid (Muhammadiyah), and Majelis Hisbah (Persis). It still seems to be the paramount choice in Indonesia, both among the public and Muslim scholars. It can be seen from the number of studies and research on fatwa institutions in Indonesia, both on the methods and the determination mechanisms (istimbat al-ahkam), theoretical foundations, to the study of produced legal products.

The number of collective fatwa studies (ijmai), according to Nugroho research,[8] differently from individual ulama fatwa $(f a r d i)$. The research on fatwa institutions in Indonesia has been published, such as M. Atho Mudzhar, who ensured that the MUI fatwa in his work was impartial and influenced by the government.[22] Indonesian Muslim scholars such as Nadirsyah Hosen,[23][24] Moch. Nur Ichwan,[25] Syamsul Anwar,[26] Ahmad Zahra,[27], and Achmad Kemal Reza.[28] Actuality, when studied in-depth and comprehensively, studying the individual fatwa ulama, often provides a significant leader and contribution. Instance, in the 19th century, the contribution of one of the Egyptian mufti, Muhammad alAbasi Al-Mahdi (1897), who wrote al-Fatawa al-Mahdiyah, was thought to have played a significant role in teaching the Hanafiyah madhab of thought in Egypt.[8]

Meanwhile, the understanding of fatwa is becoming increasingly widespread; aside from fatwa production in Indonesia, there are still complexities and challenges important to examine. Several possible issues need to be explored and addressed in greater depth.

\subsection{New Ustaz and Reintegration of Fatwa}

According to Gary R. Bunt (2003),[29] the Islamic Authority Online survey found facts about religious references among the Muslim community. More than 54 percent admitted to looking for answers to internet problems, such as popular Islamic sites, da'wah channels, and social media. This group is dominated by the younger generation (Muslim youth) whose activities cannot be separated from the Internet, especially among urban communities. Moreover, approximately 14 percent of respondents reported specifically asking experts (clerics and clerics). Roughly 32 percent replied that the issues were linked, referring to specific widely found sources such as religious books and leaflets.[1] 
The study results are strengthened by online fatwa' dominance, which has become an alternative to solving religious problems in recent years.[24] Fatwa generated through digital media is considered more effective in writing, audio, and video because all groups can access them. There have been clerical figures whose scientific and religious knowledge has been too forced and lately reinforced the online fatwa phenomenon. The resulting fatwa seems incomplete and stimulates social debate. This party, identified by the authors as "new Ustaz," is a term that refers to the rejuvenation phase of becoming a Muslim scholar (ulama). These "new ustad" groups are figures who suddenly get a Muslim scholar (Ustaz or Kiai), who previously did not have the scientific experience to express religious messages, customarily dominated by public figures.

In the new media era, with limited religious knowledge, this new gen eration is involved in building religious dynamics while simultaneously taking on significant roles that previous generations of scholars often forget. As a new generation of ulama (new Ustaz), the narrative they build simultaneously marks a shift from traditional authority to impersonal media, primarily through social media. However, this new Ustaz often creates polemics because it is easy to give fatwa - especially personal ones - without going through traditionalist ulama's processes and methodologies.

In the Islamic tradition, fatwa, whether produced through institutions or by individual scholars, has become necessary amid the complexity of society's religious issues.[4] Therefore, to ensure a reliable legal decision, a mufti must meet several qualifications that must be met: a Muslim who has matured (mukallaf), understands the ijtihad method and the objectives of sharia law( 'illat, hikmah, and maqasid al-syari'ah), has credibility and can be trusted, and must have integrity in deciding the law.[3] This criterion does not include other concerns regarding methods and concepts for formulating fatwa.

Therefore, fatwa can only be made by Muslim scholars (ulama) who know about religion. They are those who have the authority to determine every religious is sue that is taking place amid society. In Indonesia, those deemed to have authority may be an ulama that issues an individual fatwa or an ulama affiliated with an organization or institution that has the government's legitimacy.[30] Traditionally, the religious Authority in Indonesia was determined by the Ulama (Kyai or Ustadz). They are the ones who have the fatwa authority and provide interpretations of the Scriptures to alleviate problems people by issuing a fatwa. The fatwa then becomes a point of reference for people's behavior in society. They are scholars who teach the basics of Islam and instill Islamic values in the Ummah.

The fatwa entity, amid the development of new media, has made it easier to convey messages or answers to any religious issue. Simultaneously, the resulting fatwa process has transformed the fatwa tradition among the traditional ulama (salaf).[4] Moreover, a person who issues a fatwa must have a deep understanding of religion. In the commentary, Ibn Qayyim made an analogy that a pers on who gives a fatwa while not being able to do so is the same as a person who does not understand medical science but practices it. He ensured that such a mufti was not worthy of being a legal reference. Abu Hanifah made a similar comment that a mufti who has no integrity and a firm stance is like someone playing sharia law.[3]

Therefore, Jinan pointed out that some strategic measures are necessary for response to this change in authority.[1] First, ulama and religious organizations must be aware of a transformation of knowledge sources that have rapidly spread knowledge sources. Indeed, this interpretation may be said to be different from what came before it. And one thing that can easily be found in the presence of a new generation of ulama, ulama born of new media progressiveness and openness. In recent years, they have dominated most preaching on social media, often releasing inflammatory, baseless fatwa. Such scholars' presence is not entirely 
wrong; only sometimes, their presence in the da'wah world is based primarily on the spirit of transmitting information (Nasr al-Ilm) without being based on profound scientific ability.

Second, in the new media era, studying religion will be subjected to impersonal outlets that often abandon mainstream. Since new media with easy access that can be accessed anytime, anywhere, have given worrisome information. Religious messages are usually transmitted partially to the content owner's objectives and needs. Not infrequently, true religious doctrine is narrated to evoke attitudes of exclusivism, intolerance, and radicalism. [31]

Third, it is inevitable that the issues that occur in the new media era are the increasingly blurred fatwa without clear boundaries and are becoming ever more widespread.[1] Previously, it was impossible to distinguish the authority of fatwa from the role of religious institutions or organizations and individual fatwa; now, they have become fatwa formed by a new generation of the ulama. The authority rests in the fatwa have shifted in the end and have a broad interpretation.[32]

Meanwhile, these three points should be integrated into building maturity to think in response to the waning fatwa authority that occurred during the new media. Since information development can not be avoided, it must be followed simultaneously. An adaptive fatwa narrative is needed, both from the ulama affiliated with religious institutions or organizations and more so from the traditional ulama (pesantren) with an unquestioned potential resource.

\section{Conclusion}

The change in society that relies on new media has expanded the form of religious authority and changed the patterns of relations between the Ummah and the leader, requiring Muslims to reformulate how to communicate and learn a "new language" for interaction. The ongoing shift in religious authority and the implications that follow are not to be stopped. One of the most prominent examples is fatwa's authority, where everyone has the same rights and opportunities; only their scientific capacity and integrity make the difference. Many people follow personal fatwa - especially those produced by the new Ustaz - through online media networks. That marked a shift in authority from religious institutions to individual fatwa, which was later dominated by ulama's new generation. For this reason, it is necessary to address this phenomenon wisely and openly so that it does not become a narrow understanding in the middle of the new media era. As a result, the public will have a proper evaluation and attitude towards fatwa from online media networks. 


\section{References}

[1] M. Jinan, "Intervensi New Media dan Impersonalisasi Otoritas Keagamaan di Indonesia," $J$. Komun. Islam, 2013, [Online].

[2] Z. Zulkifli, "The Ulama in Indonesia: Between Religious Authority and Symbolic Power," MIQOT J. Ilmu-ilmu Keislam., 2013, [Online].

[3] Y. Al-Qardlawi, Al Fatawa bain al Indlibath wa Tasayyub. 1988.

[4] M. E. Riadi, "Kedudukan Fatwa Ditinjau dari Hukum Islam dan Hukum Positif (Analisis Yuridis Normatif)," Ulumuddin, 2013, [Online].

[5] A. Kiftiyah, "Analisis Fikih Al-Siyāsah Al-Dustūriyyah Terhadap Golput (Golongan Putih) Dalam Pelaksanaan Pemilihan Umum," core.ac.uk, [Online].

[6] M. Munthe, "Fatwa Bunga Bank Perspektif Maqashid Sy ariah," Al-Amwal, 2020, [Online].

[7] Z. Habibi, Implementasi Fatwa MUI No 7/Munas VII/MUI/11/2005 Tentang Haramnya Paham Pluralisme, Sekularime Dan Liberalisme Dalam Agama Oleh MUI Kota Pekanbaru.

[8] B. H. Nugroho, Metode Ijtihad Guru Muhammad'Ali ibn'Abd Al-Wahhab Al-Tunkali dalam Kitab Al-Fatawa Al-Tunkaliyah. Tangerang Selatan: Perpustakaan Pascasarjana UIN Syarif Hiday atullah, 2019.

[9] R. Nasrullah, Teori dan riset media siber (cybermedia). Jakarta: Prenada Media Group, 2016.

[10] G. Creeber and R. Martin, Digital culture: Understanding new media. Open University Press, 2008.

[11] L. A. Lievrouw and S. Livingstone, Handbook of new media: Social Shaping and Consequences of ICTs. London: Sage Publications Ltd., 2002.

[12] G. Krämer and S. Schmidtke, "Speaking for Islam: religious authorities in Muslim societies," Brill Academic Pub, 2006.

[13] A. Mushonnif, "Fragmentasi Otoritas Antar Organisasi Pemerintah Dan Organisasi Keagamaan Dalam Penentuan Awal Bulan Islam," AL-HUKAMA', 2013, [Online].

[14] R. Rumadi, "Islam dan Otoritas Keagamaan," Walisongo J. Penelit. Sos. Keagamaan, vol. 20, no. 1, p. 25, May 2012,

[15] J. al-D. M. ibn M. Ibn Manzur, Lisan al-'Arab. Beirut: Dar Sadr, 1997.

[16] H. Hilal, Mu'jam Mustalah al-Ushul. Beirut: Dar al-Jalil, 2003.

[17] M. Luis, Al-Mundzhid fi al-'Alam. Damaskus: Dar al-Kutub, 1978.

[18] M. Amin, Fatwa dalam Sistem Hukum Islam. Jakarta: Elsas, 2008.

[19] S. W. Al-Zuhaili, Usul al-Fiqh al-Islami. Damaskus: Dar Fikr, 1996.

[20] M. K. Masud, B. Messick, and ..., "Muftis, fatwa, and Islamic Legal Interpretation," ... Muftis their fatwa, 1996, [Online].

[21] N. J. G. Kaptein, "The Voice of The Ulamâ': Fatwa and Religious Authority in Indonesia," Arch. Sci. des Relig., 2004, [Online].

[22] M. A. Mudzhar, Fatwa-fatwa Majelis Ulama Indonesia: Sebuah Studi Tentang Pemikiran Hukum Islam di Indonesia, 1975-1988. INIS, 1993.

[23] N. Hosen, "Religion and The Indonesian Constitution: A Recent Debate," J. Southeast Asian Stud., 2005, [Online].

[24] N. Hosen, Online Fatwa in Indonesia: From Fatwa Shopping to Googling a Kiai. ro.uow.edu.au, 2008.

[25] M. N. Ichwan, "'Ulamā', State and Politics: Majelis Ulama Indonesia After Suharto," Islam. Law Soc., 2005, [Online].

[26] S. Anwar, "Fatwā, Purification, and Dynamization: A Study of Tarjīh in Muhammadiyah," Islam. Law Soc., 2005, [Online].

[27] A. Zahro, Tradisi Intelektual NU: Lajnah Bahtsul Masa 'il, 1926-1999. Yogyakarta: PT LKiS Pelangi Aksara, 2004.

[28] A. K. Riza, "Contemporary Fatawa of Nahdlatul Ulama: Between Observing the Madhhab and Adapting the Context," J. Indones. Islam, 2011, [Online].

[29] G. R. Bunt, Islam in The Digital Age: E-Jihad, Online Fatwa, and Cyber Islamic 
Environments. London: Pluto Press, 2003.

[30] A. Azra, "Pemencaran Otoritas Keagamaan," Republika, Kamis 5 Juli, 2005.

[31] I. F. Ghifari, "Radikalisme di internet," Relig. J. Stud. Agama-Agama dan Lintas Budaya, vol. 1, no. 2, pp. 123-134, 2017.

[32] N. A. F. Fauzi, "Fatwa di Indonesia: Perubahan Sosial, Perkembangan dan Keberagaman," J. Huk. Nov., 2017, [Online]. 